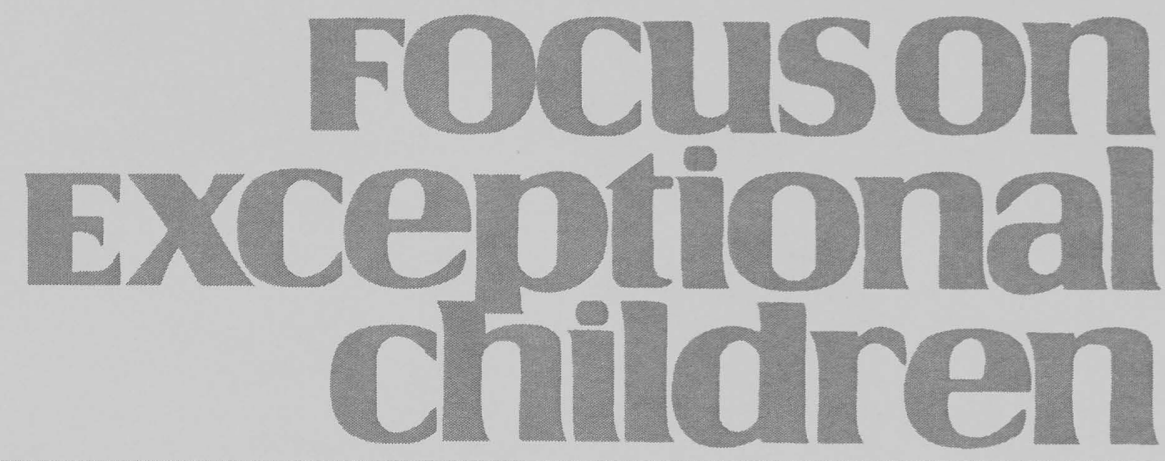

\title{
Transforming Special Education Teacher Education: A Reaction to the Report Transforming Teacher Education through Clinical Practice: A National Strategy to Prepare Effective Teachers
}

\author{
Jennifer R. Newton, Michael J. Kennedy, Christine Walther-Thomas, and Jake Cornett
}

Policy makers, university teacher education faculty, school leaders, and government officials are asking the same question: How do we recruit, prepare, and retain effective teachers who will produce desired student outcomes in every classroom? This complex question garners distinct opinions depending on the queried stakeholder, but most agree that significant improvement is needed in the processes of teacher preparation and induction (Darling-Hammond, 2010; Greer \& Meyen, 2009; Sykes, Bird, \& Kennedy, 2010; Wang, Odell, Klecka, Spalding, \& Lin, 2010). An argument can be made that the need for improvement is most urgent within the field of special education teacher preparation (Brownell, Sindelar, Kiely, \& Danielson, 2010; Piper, 2007; Pugach, Blanton, \& Correa, 2011; Simonsen et al., 2010; Sindelar, Brownell, \& Billingsley, 2010).

To illustrate, recent achievement data for students with disabilities provides striking evidence of the critical need for improvement in areas of literacy, graduation rates, and other postsecondary outcomes (e.g. National Center for Education Statistics [NCES], 2009; Wagner, Newman, Cameto, Levine, \& Garza, 2006). There is substantial variability in the numerous factors that contribute to the struggles of students with exceptionalities on measures of academic and social success (see Skiba, Poloni-Staudinger, Simmons, FegginsAzziz, \& Chung, 2005; Wagner et al., 2006). Many complex factors influence a teacher's impact on student achievement, which leads to the need for us to continue to examine and reform our current models of teacher preparation. Thus, teacher educators and practitioners must continue to investigate and evaluate the effects of new and existing policies, programmatic structures, and individual practices on outcomes of interest and disseminate those findings.

Although calls to reform teacher education and P-12 instruction for children with exceptionalities are not new (Vaughn \& Fuchs, 2003), it is clear that new thinking is needed to overcome traditional barriers to academic and social success for individuals with exceptionalities. However, despite the critical need for improvement, teacher preparation models within special and general education largely remain fixed to traditional methods

Dr. Newton is an assistant professor in the Exceptional Education Department at James Madison University. Dr. Kennedy is an assistant professor in the Curriculum, Instruction, and Special Education at the University of Virginia. Dr. Walther-Thomas is dean of the School of Education at Virginia Commonwealth University. Mr. Cornett is Joseph P. Kennedy, Jr. Foundation Public Policy fellow in the United States Senate. 
that reflect the status quo as opposed to evidence-based practice (Boyd, Grossman, Lankford, Loeb, \& Wycoff, 2009; Brownell, Griffin, Leko, \& Stephens, 2011; Sykes et al., 2010).

\section{ISSUES RELATED TO SPECIAL EDUCATION TEACHER PREPARATION PROGRAMS}

Regardless of programmatic purpose and intent, many in the field agree that field experiences, pedagogy, and knowledge of subject matter are three critical components all teachers must have as a foundation for effective teaching (Darling-Hammond, 2010; Darling-Hammond \& Bransford, 2005). Most traditional and alternative teacher preparation programs are grounded in an established theoretical framework (e.g., Darling-Hammond \& Bransford, 2005; Hollins, 2011); however, empirical evidence for validating one model over the other has yet to emerge (Brownell, Ross, Colón, \& McCallum, 2005; Darling-Hammond, 2010; Wang

\section{FOcuson Exceptional children}

ISSN 0015-511X FOCUS ON EXCEPTIONAL CHILDREN (USPS 203-360) is published monthly except June, July, and August as a service to teachers, special educators, curriculum specialists, administrators, and those concerned with the special education of exceptional children. This publication is annotated and indexed by the ERIC Clearinghouse on Handicapped and Gifted Children for publication in the monthly Current Index to Journals in Education (CIJE) and the quarterly index, Exceptional Children Education Resources (ECER). The full text of Focus on Exceptional Children is also available in the electronic versions of the Education Index. It is also available in microfilm from Serials Acquisitions, National Archive Publishing Company, P.O. Box 998, Ann Arbor, MI 48106-0998. Subscription rates: individual, \$50 per year; institutions, \$68 per year. Copyright (C) 2012, Love Publishing Company. All rights reserved. Reproduction in whole or part without written permission is prohibited. Printed in the United States of America. Periodical postage is paid at Denver, Colorado. POSTMASTER: Send address changes to:

Love Publishing Company

Executive and Editorial Office

P.O. Box 22353

Denver, Colorado 80222

Telephone (303) 221-7333

\section{CONSULTING EDITORS}

Steve Graham Vanderbilt University
Ron Nelson

University of Nebraska-Lincoln
Eva Horn

University of Kansas et al., 2010). Despite support from federally funded research centers (e.g., Center on Personnel Studies in Special Education), substantial public attention (e.g., National Council for Accreditation of Teacher Education, 2010), and research (e.g., Cochran-Smith, 2005), there is little consensus with respect to the "best" pathway to teacher preparation (Kennedy, 2005). Although there are logical reasons for heterogeneity among teacher preparation programs (e.g., elementary preparation, secondary preparation), this heterogeneity also contributes significant variability to the knowledge and skill sets of candidates who complete the respective preparatory programs (Boyd et al., 2009).

Experts in the field of special education augment this list with readiness of educators to embed individualized instructional practices within content-specific demands of the general education curriculum (Brownell et al., 2010; Kennedy \& Ihle, 2012; McKenzie, 2009; Oyler, 2011). To date, there is little evidence to guide teacher preparation programs in construction of instructional models addressing the complex and voluminous demands placed on special education teachers (Brownell et al., 2011; Pugach et al., 2011; Sindelar et al., 2010). To some extent, the limited empirical guidance is a function of both the heterogeneity of preparatory programs (Brownell et al., 2005) and the substantially different instructional settings within individual districts and schools (KingSears \& Bowman-Kruhm, 2011; McKenzie, 2009).

\section{Roles of Special Educators and Implications for Teacher Preparation}

Special educators must be ready to teach students with a wide variety of instructional needs and disabilities across multiple grade levels and in rigorous content areas (Brownell et al., 2005; Brownell et al., 2011; Kennedy \& Ihle, 2012; McKenzie, 2009). Regardless of grade level or content area, a chief concern of special educators is their capacity to promote individualized instruction among students resulting in student achievement (Edmonds et al., 2009; Faggella-Luby \& Deshler, 2008; Kennedy \& Deshler, 2010). Capacity is constructed and sustained though implementation of evidence-based practices, including explicit and strategic instruction (Ebbers \& Denton, 2008; Scammacca et al., 2008; Scruggs, Mastropieri, Berkeley \& Graetz, 2010). A frequent recommendation in the professional literature that preparing preservice and in-service teachers to provide evidence-based literacy instruction should be a cornerstone of teacher preparation programs and ongoing professional development (Brownell et al., 2010; Shanahan \& Shanahan, 2008). In special education, however, the translation of evidence-based instructional practices from the research laboratory into teacher preparation coursework and classroom implementation remains a significant area for improvement 
(Brownell et al., 2011; Deshler \& Schumaker, 2006; Pugach et al., 2011; Sindelar et al., 2010).

Special educators must also be prepared to work collaboratively with general education teachers across a range of frequently ill-defined and poorly supported coteaching scenarios and content areas (Billingsley, 2004; King-Sears \& Bowman-Kruhm, 2011; Mastropieri et al., 2005; McKenzie, 2009; Oyler, 2011). In addition, they must keep up with paperwork requirements and maintain ongoing communication with families and a range of professionals (Billingsley, 2010). In many ways, special educators face unfair and impractical expectations with respect to the vast range of knowledge and practices required to support students with special needs across diverse academic expectations (Kennedy \& Ihle, 2012). Guidance from national accreditation groups such as the National Council for Accreditation of Teacher Education (NCATE), now known as The Council for the Accreditation of Education Preparation after a merger with the Teacher Education Accreditation Council, may offer useful frameworks for improving methods to prepare general and special educators, who are required to continuously improve measurable outcomes for all students. However, translating reform frameworks into observable and measurable practices at scale is much easier to conceptualize than to implement (Cuban, 2008; Fullen, 2007).

While special education preparation programs expose candidates to evidence-based practices and provide training writing IEP goals and in various collaboration techniques (see Brownell et al., 2005), there are no set curricula or prescribed experiences comprehensively preparing candidates for the wide array of instructional settings in which they may be asked to serve. One reason for this is that expectations placed on special educators in the field are wildly diverse and unpredictable with respect to daily duties (McKenzie, 2009). In other words, each district and school maintains its own interpretation of instructional settings for students with disabilities. This inconsistency among schools is not inherently negative; however, at the teacher preparation level, it is impractical to provide training for a wide variety of ultimately unpredictable instructional settings (Sykes et al., 2010). For example, in some schools, special educators are required to teach subject-specific content to small groups of students. In others, the special educator plays a support role to a content specialist in the general education classroom. And, in others still, special educators split time among multiple instructional settings. Therefore, it is largely unfair to criticize schools of education for the frequent mismatch between preparation and the reality of special education settings in schools. Although general education teacher preparation programs face mismatches of their own between institutional curricula and the various curricula used by school districts (cf. Wang et al., 2010), special education is further set apart from other programs within the field of teacher education, given the difficulty in clearly and consistently specifying what special education is and looks like in multiple settings (Brownell et al., 2011; Pugach et al., 2011).

\section{The Role of NCATE in Improving Teacher Preparation}

Schools of education seeking accreditation from NCATE are required to demonstrate a cohesive, evidence-based, competency-centered curriculum that will prepare effective teachers (NCATE, 2010). Nearly 700 teacher preparation programs in the United States are NCATE accredited, a process that indicates a commitment to and focus on effective teacher preparation. However, the accreditation process is only one piece of the puzzle when it comes to instituting effective teacher preparation practices that can be correlated with student performance in the classroom (Hollins, 2011; Stronge, Ward, \& Grant, 2011). Given increasing public demands for highly effective teachers and little definitive research available about the appropriateness of various teacher preparation approaches, stakeholders (e.g., state and federal policy makers, school professionals, field researchers, and professional organizations) have taken note (Boyd et al., 2009; Pugach \& Blanton, 2011; Wang et al., 2010). Although widely disseminated attention is typically given to the struggles of teacher preparation as a generic whole (cf. Ed Week), there is significant need to be more precise with respect to the uniqueness of teacher preparation in the field of special education (Brownell et al., 2010; Sindelar et al., 2010).

In response to the ambiguity in teacher preparation, NCATE commissioned a panel to develop a roadmap for improving teacher education through transformative learning and development experiences. In November 2010, NCATE released Transforming Teacher Education through Clinical Practice: A National Strategy to Prepare Effective Teachers. This blue-ribbon committee made up of leaders in teacher education policy and research calls for a focus on high-quality supervised field experience supported with pedagogy and content-driven coursework. The report recommends a shift toward a more "clinical" approach to teacher preparation loosely modeled after teaching hospitals that prepare medical professionals. Predictably, the NCATE report does not specifically address special education teacher preparation; however, the recommendations do have relevance for our field, therefore providing critical impetus for scholarly debate.

The unique responsibilities and expectations special educators face in the classroom must be addressed in preparation programs (Billingsley, 2004; Pugach \& Blanton, 2011; Pugach et al., 2011). However, current methods used to 
prepare future educators are as diverse as the students they will teach and as the research findings that support various approaches to teacher licensure (Brownell et al., 2011; Sindelar et al., 2010). The NCATE report (2010) is significant and timely, given substantial pressure levied on educational stakeholders to improve the quality of teacher preparation (Duncan, 2010; Hess, 2010). Ironically, this pressure stems largely from the ambiguity of the various models of teacher preparation existing today in the field.

\section{An Argument in Favor of Reform}

Our position on reforming special education teacher preparation is anchored in (a) an analysis and discussion of the implications of the NCATE report's recommendations for improving teacher preparation and (b) the context of two differing perspectives on special educators' roles and responsibilities recently published in the professional literature (i.e., Brownell et al., 2010; and Simonsen et al., 2010). The conclusion of our analysis and discussion will yield recommendations for policy makers, teacher educators, and other stakeholders with respect to reshaping teacher preparation in the field of special education. This discussion is particularly relevant given the ongoing discourse in the literature related to whether or not teaching is a profession with the same respected standing and standards as medicine, law, and engineering (Wang et al., 2010).

\section{NCATE REPORT RECOMMENDATIONS}

\begin{abstract}
We need teachers who are well versed in their curricula, know their communities, apply their knowledge of child growth and development, use assessments to monitor student progress and effectively engage students in learning. Teachers need collaboration, communication, and problemsolving skills to keep pace with rapidly changing learning environments and new technologies. (NCATE, 2010, p. 1)
\end{abstract}

The authors of the NCATE (2010) report emphasize the need to create and prioritize carefully constructed and monitored clinical learning experiences for teacher candidates above traditional experiences, such as coursework on theory and pedagogy. Under this model, theory and pedagogy are not abandoned but rather continuously intertwined with clinical experiences to create an authentic and effective preparation program. To operationalize their new construct for teacher preparation, the NCATE report presents five recommendations:

1. More rigorous accountability

2. Strengthening candidate selection and placement

3. Revamping curriculum, incentives, and staffing

4. Supporting partnerships

5. Expanding the knowledge base to identify what works and support continuous improvement
More rigorous accountability. The first recommendation by the NCATE panel is to increase accountability for institutions of higher education (IHEs) by tying the academic performance of $\mathrm{P}-12$ students to past graduates of teacher preparation. Although this type of accountability measurement is difficult to define, stemming from the diverse and complicated barriers related to the structures of IHEs and school districts (Boyd et al., 2009; Sykes et al., 2010; Wang et al., 2010) as well as the imprecise nature of measurement in schools (National Research Council, 2010), the panelists call for new paradigms and methods to reduce these barriers. According to the report, in order for accountability to be tightly linked between teacher preparation programs and P-12 student learning, school districts and teacher preparation programs must forge tighter relationships. This includes the need for districts to have a hand in designing teacher preparation programs that lead to candidates who are well prepared for the specific challenges of their instructional setting. Preparing teacher candidates for success in highly contextualized instructional settings will require curriculum sharing and streamlining between the teacher preparation program and the district. In addition, the report calls for local districts to have input on which teacher candidates are selected to work in their schools during clinical experiences. Finally, the panelists recommend all teacher preparation programs be held to the same standards to reduce variability among programs. The issue of programmatic variability, as discussed above, can lead to numerous and stubborn challenges in giving candidates the knowledge and experiences they need to become successful educators.

Strengthening candidate selection and placement. The second recommendation from the report (NCATE, 2010) is to make improvements in methods used by teacher preparation programs to recruit and select teacher candidates. Although most programs use GPA and scores on standardized assessments such as the SAT and ACT for acceptance decisions, the panel recommends using other criteria, such as measures of "leadership, persistence, commitment, and facility with oral and written communication" (NCATE, 2010, p. 18). By evaluating candidates using a number of objective and subjective criteria, it is possible to recruit candidates who possess both the tangible and intangible characteristics of effective teachers into the field.

Revamping curriculum, incentives, and staffing. The third recommendation from the NCATE panel is to revamp the curriculum for teacher preparation programs, change incentive structures for faculty members and teachers, and adjust staffing decisions made by teacher preparation programs and districts. With respect to curriculum changes, it is suggested that teacher preparation programs and districts should "develop a deliberate, seamless curriculum that spirally integrates coursework and laboratory experience with 
extended embedded school experiences" (NCATE, 2010, p. 19). There is also a call for teacher candidates to learn about, implement, and evaluate multiple methods for assessment used for evaluating student learning and effects of teaching. Additional knowledge about assessment techniques will permit teacher candidates and novice teachers to extend their capacity to carefully evaluate student progress and make instructional decisions.

The panel (NCATE, 2010) calls for the increasing role and legitimization of clinical faculty members within the traditional hierarchy of teacher preparation faculty members. This would include changing models for how promotion and tenure would be calculated and awarded by IHEs. Clinical faculty members also play an important role in the hierarchy of school districts in the model described by the NCATE panel. Most school districts do not provide strong incentives for mentoring teacher candidates or new teachers, nor do they provide adequate professional development to support practices used during mentoring (Sykes et al., 2010). All preservice and novice educators should have access to highly qualified and highly competent clinical faculty and have the opportunity to learn alongside master teachers as well. To accomplish this goal, however, will require new professional development sessions and models for existing educators. This is critical, as some researchers note the wide variability in quality of mentoring that teacher candidates and novice educators receive (Wang et al., 2010; Sykes et al., 2010).

Supporting partnerships. The fourth recommendation is for state lawmakers and education leaders to remove funding barriers preventing districts and teacher preparation programs from working seamlessly together. Funding streams provided by state and the federal governments would greatly augment the likelihood these recommendations would take hold. The NCATE panel calls for incentives to be provided in order to support preparation programs that prepare teachers to work in hard-to-staff schools and teaching areas, such as special education. The structural changes to teacher preparation programs called for by the NCATE report would also de-incentivize teacher preparation programs from churning out more graduates than partnering school districts need. This market-based mentality is intended to help teacher preparation programs become more selective in the admissions process. In other words, the panel suggests fewer candidates would be accepted; however, those completing the program would be of higher quality and more easily and quickly employed.

Expanding the knowledge base to identify what works and support continuous improvement. Finally, the NCATE panel recognizes the dearth of empirical evidence available to recommend teacher preparation programs utilize specific practices or structures. Therefore, it recommends that the government invest in cycles of research and development to identify successful programs and the practices and structures that result in measurable effectiveness. NCATE is well positioned to create a network of data that can be shared among member schools to ensure the best information is being disseminated as widely as possible.

\section{Design principles for clinically based preparation}

In addition to the five recommendations, the NCATE panelists provide ten design principles for creating and implementing their concept of clinically based preparation.

1. Student learning is the focus.

2. Clinical preparation is integrated throughout every facet of teacher education in a dynamic way.

3. A candidate's progress and the elements of a preparation program are continuously judged on the basis of data.

4. Programs prepare teachers who are experts in content and how to teach it, and who are also innovators, collaborators, and problem solvers.

5. Candidates learn in an interactive professional community.

6. Clinical educators and coaches are rigorously selected and prepared and drawn from both higher education and the $\mathrm{P}-12$ sector.

7. Specific sites are designated and funded to support embedded clinical preparation.

8. Technology applications foster high-impact preparation.

9. A powerful $R \& D$ agenda and systematic gathering and use of data supports continuous improvement in teacher preparation.

10. Strategic partnerships are imperative for powerful clinical preparation.

Although these design principles seem to be highly logical and consistent with other calls for teacher preparation reform (cf. Darling-Hammond, 2010; Wang et al., 2010), the structural, pedagogical, and practical implications for teacher preparation programs and school districts may provide a stumbling block for long-term implementation and sustainability. Half of these design principles are likely beyond the immediate control of most teacher education faculty members or school officials (i.e., principles 2, 6, 7, 9 and 10). Thus, new and bold thinking is needed to implement the remaining principles into existing practices of teacher educators.

\section{Implications of the NCATE Report on Special Education}

In light of the NCATE report (2010), the preparation of special educators may need dramatic reconstruction to meet 
the needs of students with disabilities in the $\mathrm{P}-12$ classroom. For example, in addition to the NCATE report, there has been a move among policy makers and the current federal administration to focus on a common core group of standards for all school children in the United States. The common core state standards (CCSS) are the result of a partnership between the National Governor's Association (NGA) and the Council of Chief State School Officers. The CCSS focus on embedded literacy practice across the curriculum with an emphasis on higher order thinking and problem solving. Teachers, school administrators, and state education agency (SEA) experts collaborated to develop a "clear and consistent framework to prepare our children for college and the workforce" (NGA, 2010, http://www.corestandards.org). The bipartisan Health Education Labor and Pensions Senate committee bill to reauthorize the Elementary and Secondary Education Act (ESEA) supports state adoption of CCSS with a focus on college and career preparation for $\mathrm{P}-12$ students. As curricular expectations for students and funding opportunities for states and universities shift in this direction, so too must the preparation and skill set for teacher candidates. However, given the newness of the CCSS and uncertainty surrounding the ESEA reauthorization, finding specific guidance teacher preparation programs can use to augment or change existing curricula and practices is difficult.

The language of all students used throughout the Senate ESEA reauthorization bill and CCSS documents indicates that special educators define the skill sets, roles, and ultimately, measurable student outcomes for which we are accountable. Despite the availability of funds from the federal government, the NCATE report and the CCSS are silent with respect to how recommendations will translate to effectiveness in classrooms. If the recommendations are to be adopted and result in measurable student learning gains, teacher preparation programs must play a substantial role, and field experience may bridge the gap between preparation coursework and real-world experiences.

\section{Field Experience in Teacher Preparation}

Field experience, or student teaching, has long been considered an integral part of teacher preparation (Carnegie Forum on Education, 1986). However, in order to bridge the gap between theories taught in higher education classrooms and practices in the $\mathrm{P}-12$ classroom, field experiences must provide more than a place for a student to observe a veteran teacher at work (Albers \& Goodman, 1999; Prater \& Sileo, 2004). Students who apply practices and strategies learned during coursework, receive guidance and support from their cooperating or mentor teacher, and then reflect on those experiences report higher levels of readiness and satisfaction in their induction years as teachers (Andrew \& Schwab, 1995).
Significant time in the field prior to graduation may also serve to bridge the gap between theory learned in coursework and the actual practice of teaching (Zeichner, 2010). New teachers often report feeling ill prepared for the work of educating students, learning and maneuvering effectively within the school culture, and managing paperwork, nonteaching responsibilities, and the expectations and needs of their students' families (Billingsley, 2004; Brownell \& Smith, 1992). Limited or lack of preparation with respect to critical elements of teaching is a contributor to the high rate of turnover in the field (Feiman-Nemser \& Buchmann, 1985).

Researchers have found that simply increasing time in the field, however, does not necessarily result in better preparation of teachers or higher student teacher satisfaction (Capraro, Capraro, \& Helfeldt, 2010). While the research is limited, investigators have found that contributing factors such as quality of the site, mentor teacher skills, quality of the supervision, and student teachers' classroom preparation contribute to the preparatory benefits of field experience (Capraro et al., 2010; Zeichner, 1980; 2010). The NCATE report recommends hands-on preparation beyond traditional field experience by adopting a teaching hospital model, as is commonplace in medical training. The report calls for a fully-integrated teacher preparation program in which pedagogy, content knowledge, and coursework come together in a supported teaching and learning school environment. Preparation of this kind would require the teaching and engagement of special education faculty as well as the development of learning communities where every member in every role is viewed as a teacher and a learner (Coulter, 2003). In order for this to happen, effective and sustainable partnerships between university teacher preparation programs and districts and schools must be established.

\section{School/University Partnerships}

Although the literature on implemented and measured school-university partnerships is sparse, a framework is emerging with four key components of effective and successful partnerships (see Peel, Peel, \& Baker, 2002). LefeverDavis, Johnson, and Pearman (2007) describe the first component in suggesting school districts and universities should consider their mutual histories, relationships, work styles, and expectations prior to entering a school-university partnership. The literature is clear with regard to the second component in emphasizing an established goal with an articulated plan to achieve it is essential for effective partnerships (Darling-Hammond \& McLaughlin, 1995; Donovan, 2009; Peel et al., 2002). Preparing effective teachers who will promote student learning and outcome measures is a strong priority for both university faculty and district and local school administration. The NCATE report provides 
examples of effective district or school-university partnerships to serve as models for collaborating on teacher preparation and coordinating funding sources. However, the practice has yet to scale up to encompass the many and varied special education teacher preparation programs across the country.

Partnerships present unique challenges to teacher education faculty in higher education (Stephens \& Boldt, 2004); addressing these challenges is the third component of successful school-university partnerships. The incentive structure of tenure and promotion makes sustained collaborative work challenging (Byrk \& Gomez, 2008). However, with national funding competitions such as race to the top (RTTT) and Investing in Innovation (i3), there has been a transition from formulary funding of public education to a greater focus on competitive awards, a skill rewarded in the structure of tenure and promotion at IHEs. With this shift, higher education faculty who traditionally drove the research agenda must adjust to an environment of mutually beneficial and collaborative partnerships. Although this change is significant in its potential to foster partnerships, it has several consequences. School-university partnerships for the purpose of competitive funding usually remain only as long as the funding continues. Further, these arrangements often benefit large or suburban districts that can afford grant writers and administrators, while shortchanging small, rural, or poor school districts lacking capacity for this type of competition. Nevertheless, competitive funding opportunities may serve as impetus for encouraging school- university partnerships insofar as the competition is designed to address the challenges of developing the partnership.

Carlone and Webb (2006) reported on their own experiences as university faculty collaboratively working with three 3rd-grade science teachers with the intent of challenging the traditional knowledge hierarchy of university faculty member to teacher to student. The researchers found, despite their best and intentional efforts, the underlying power differential and perceived hierarchy elevating the knowledge of university faculty over that of the participating teachers ultimately affected the efficacy of their partnership. The fourth component of successful school-university partnerships is to address the perceived hierarchy of faculty and teachers. Successful partnership between faculty and teachers is characterized by collaboration where each recognizes and values the contributions of the other.

Partnerships between schools and college- and university-based teacher preparation programs can establish a culture where both the university and local districts carry responsibility for teachers as professionals working in conjunction with the mutual goal of promoting student outcomes through effective teachers. While preparing teachers for the complex and dynamic work of educating students currently falls primarily on schools of education in college and university settings, supporting and retaining teachers through mentoring and professional development is primarily the responsibility of school districts (Cozza, 2010). In an effort to share resources, focus problem solving, and improve educational outcomes for students, collaborative school-university partnerships are promoted by NCATE as an emerging model with strong potential for mutually beneficial teaching and learning.

\section{VIEWS OF SPECIAL EDUCATION TEACHER ROLES AND RESPONSIBILITIES}

Teaching is complex and requires a specific skill set (Cochran-Smith, 2005; Darling-Hammond, 2007). Students identified with special needs currently perform considerably below their peers who are typically developing (Wagner et al., 2006), and research supports the importance of high quality teachers, over all other variables, to affect performance in students (Harris \& Sass, 2009). Therefore, increasing attention is turning to preparation experiences and to how the field of special education wants to position the role of special educators in the future (Pugach \& Blanton, 2011). As a result, special education teacher educators are discussing the roles and responsibilities of special educators in the multitiered educational systems (Brownell et al., 2010; Kennedy \& Ihle, 2012; Simonsen et al., 2010).

Special education teacher preparation curricula are generally designed to comply with recommendations determined through consensus of stakeholders in professional organizations to guide teaching practices in special education. However, established requirements have little empirical basis (Sindelar et al., 2010). Sindelar and his colleagues raised more questions than answers in their analysis of special education teacher preparation and its approaches, priorities, experiences, and outcomes for students. It is clear that more empirical research is needed to support the various theories and existing practices that are used within our field.

Two recent articles frame special educators in two distinct roles. Brownell and colleagues (2010) present a framework of special educators as coteachers who require extensive knowledge in language, literacy, and math in order to support students and general education teachers. Simonsen and her colleagues (2010) recommend the reconceptualization of special educators as interventionists who serve students with exceptionalities across settings in schools implementing tiered instructional systems. These contrasting views of special educator preparation provide a useful launching point for exploring how special education teacher preparation programs can address and, to the extent appropriate, adapt to some or all the changes called for in the NCATE (2010) report. 


\section{Special Educators as Coteachers}

Brownell and colleagues (2010) make the case that special educators need a strong and thorough knowledge base in the content areas of literacy, language, and numeracy in order to teach and provide interventions to support learning for students with disabilities. Given a three-tier model of instruction (see Mellard, Stern, \& Woods, 2011), Tier 2 and, more intensively, Tier 3 accommodations and interventions are the responsibility of special educators (Brownell et al., 2010). Brownell and colleagues envision an opportunity for special educators to define a specific role and skill set, thus informing the necessary preparation experiences to meet the needs of all students.

Teaching content to a variety of learners, presenting information with multiple means of representation, and understanding how learners think, process, and learn are all strengths brought to the general education classroom by special educators (Scruggs, Mastropieri \& Duffy, 2007). These strengths are among special educators' strongest assets and must be maximized in tiered educational systems (Mastropieri et al., 2005). However, ESEA does not require all teachers to demonstrate knowledge and skills in the subject area in which they teach. Current law permits teachers who are still in training in alternative route programs to be labeled as highly qualified. This requirement includes special educators who work across grade levels and in specific content areas (McKenzie, 2009). Acquiring the skills required to teach across grade levels and in multiple content areas requires extensive training before demonstrating proficiency in both special education and one or more subject area.

Most stakeholders agree that a comprehensive understanding of the content is imperative to a teacher's efficacy, but, for special educators, the definition of a consistent set of content knowledge and practices is ambiguous and vague at best (Hill, Ball, \& Schilling, 2008). Brownell and colleagues' (2010) recommendations for special education teacher preparation call for advanced coursework in literacy and domain expertise. Their argument is driven by the need for special educators to be equals with general educators with respect to content knowledge but also be experts in methods for differentiating instruction for all learners. Brownell and colleagues' argument is reminiscent of Shulman (1986), who said knowledge of a subject area is not enough; effective teachers also need a solid foundation of content-appropriate pedagogical practices.

In summary, Brownell and her colleagues $(2010,2011)$ recommend integrating teacher preparation for general and special educators because strengths from both disciplines are necessary to implement an effective tiered model of intervention. They state, "preparation now must help general and special education teachers integrate evidence-based practices into content instruction" (p. 371). This wording is important because it charges both general and special educators with the task of obtaining the knowledge, understanding, and pedagogy to teach all learners across all standards. This is a dramatic change in structure from the tracks of general or special education preparation on which students have typically been prepared. This will be difficult to accomplish given the current structure of teacher preparation in higher education. However, unified early childhood education models and dual licensure programs provide opportunity to investigate the preparation of teachers skilled in both content and in meeting the needs of diverse learners. It is also important to note efforts have been made to embed knowledge, skills, and practices from special education into conventional teacher preparation programs (Imig, Wiseman, \& Imig, 2011).

\section{Special Educators as Interventionists}

Simonsen and her colleagues (2010) present an alternative model from which to view the role of special educators in a tiered educational model. They place emphasis on the "careful implementation of evidence-based instruction and curriculum, administrative support, redistribution of resources, professional development, a commitment to data-based decision making, and a symbiotic relationship between general and special education" (Simonsen et. al, 2010, p. 22). They promote special educators as interventionists for all students: Special educators serve as coaches of general educators who then collaborate in the implementation of a tiered system of support. Given this role, special educators should be prepared as such. Rather than focusing on content knowledge, in this model, special educators must be prepared to lead, collaborate, problem solve, and intervene as needed to make curriculum accessible for all learners. This is different from the Brownell et al. (2010) model because special educators are not responsible for the initial delivery of content but for transforming content in meaningful ways for a diverse population of learners.

Within the interventionist model (Simonsen et al., 2010), special educators will continue to bear the legal responsibility for special education services received (e.g., documentation, data collection, and IEP development and maintenance) but will also gain the new responsibilities of coach, professional developer, consultant, and interventionist. Special educators move away from working closely with a select few students with the greatest needs to working with all students and general educators to build capacity in differentiating instruction and meeting diverse learner needs. Special educators bring a skill set conducive to this role because they are prepared with specific evidence-based instructional strategies to support struggling learners (Deshler \& Schumaker, 2006). However, special educators are currently prepared for 
direct instruction in a collaborative environment rather than as instructional coaches and professional developers. Therefore, implementation of this model may require an overhaul of teacher preparation as well as in role recognition for special education professionals within the contexts of schools.

\section{ANALYSIS AND RECOMMENDATIONS}

Defining the roles and purposes of special education in the classroom is an imperative first step in applying the NCATE panel's (2010) recommendations to teacher preparation of special educators. Brownell and colleagues (2010) and Simonsen and colleagues (2010) provide two of the visions for reforming teacher preparation; however, opinions and ideas for reform are not limited to these models. That said, both are extraordinarily different from broad, generalist, current practices in special education. Here we provide recommendations for engaging special education teacher educators in the debate, encouraging NCATE to invite the field of special education to the table.

\section{For Policy Makers}

Teachers are responsible for the learning outcomes of all students. Therefore, the oversight of special education in the NCATE report is significant. Policy makers should be more careful to include legislative language specifically recognizing the individualized learning needs of students with exceptionalities. Although the language "all students" is used in the NCATE and other reports, this provides too little emphasis on the learning needs of students with disabilities. Establishing a definition for the role of special educators and a model for the instructional settings students with special learning needs require for success is a critical missing component of the NCATE report. An essential step forward in improving outcomes for students with special needs would be the creation of federal and state standards or guidelines for elementary and secondary schools with respect to preferred instructional configurations that benefit students with exceptionalities. The streamlining of how schools make decisions regarding the creation of instructional settings for students with exceptionalities would significantly reduce variability in how students are taught and thus provide teacher preparation programs with less heterogeneity to contend with when preparing teachers.

\section{A Short and Long-Term Plan for Reform}

In 2002, the No Child Left Behind Act was signed into law and was scheduled for reauthorization in 2007. Now, more than 10 years after the law was signed, Congress has taken up reauthorization. As we consider the legislative history, to reform the relationships between teacher education programs, schools, researchers, and educators, a 10-year plan will be necessary. The 10-year plan should aim to influence policy during reauthorizations of each federal education law; that is, the Higher Education, Individuals with Disabilities Education, and Elementary and Secondary Education Acts. Recognizing there is much we do not know about the preparation of highly qualified special educators who produce measurable learning outcomes for students with disabilities, we offer recommendations for developing the 10 -year plan for teacher preparation reform (see Figure 1). The plan includes three phases, developing and demonstrating, evaluating outcomes, and influencing policy. In short, an ambitious

Development and Demonstration

Rigorous requirements for highly effective teachers

Heavy investment in

development and research

of partnership models of

preparation

Field-based preparation program

Sustained and ongoing professional development for master teachers

\section{Process and Evaluation}

Measured by

- student outcomes

- teacher candidates

- master teachers
Policy and Reauthorizations

Lessons learned

Repurposing current

funding allocations

Measuring implications for the Higher Education Act, IDEA, and ESEA 
research and development agenda is presented, bringing together experts in the areas of elementary, secondary, special, bilingual, and higher education.

\section{Development and demonstration}

The initial stage of the short- and long-term plan for reform embarks on a dramatic change in research, development, and implementation of teacher preparation. The purpose of this phase is to identify specific goals and plans, create empirical models of reform, and demonstrate the effects while documenting the necessary inputs for implementing reform. In this phase, teacher educators must engage in innovation, creating various versions of reform to identify those reform models leading to improved outcomes. After divergence, the field must coalesce around a set of high standards for teacher candidates and in-service teachers to demonstrate. To develop the necessary support among policy makers and consumers of higher education, the field should demonstrate the reforms lead to a pattern of positive growth in student outcomes as measured by a variety of qualitative and quantitative data points. The federal government and nonprofits such as the Bill and Melinda Gates Foundation could promote this phase by providing significant financial support for reform, thereby providing seed money for schools and university faculty to reorganize, implement, and evaluate school-university partnerships and clinical teacher preparation.

Because of the wildly diverse roles of special educators in schools, partnerships will use state standards for teacher licensure to guide the required competencies and experiences for preservice teacher preparation. Preservice teachers should spend a minimum of half of their required course time in a field-based setting. Boyd and his colleagues found preparation that "focuses more on the work of the classroom and provides opportunities for teachers to study what they will be doing as 1st-year teachers seems to produce teachers who, on average, are more effective during their 1st year of teaching" (Boyd et al., 2009, p. 434).

Also during this phase of the plan is the development of mutually beneficial partnerships as illustrated in Figure 2 . Preservice teachers, inservice teachers, and university faculty engage in structured support and knowledge exchange that improves the practice of each individual. This, in itself, has vast potential for reshaping teacher preparation.

\section{Quality Process and Data-Based Outcome Evaluation}

The purpose of this phase is to develop systems for ongoing formative and summative evaluation of the teacher training models. Formative evaluation of the clinical experiences of teacher candidates is essential to continuous improvement of the model. And equally important is summative evaluation, including sound systems for monitoring

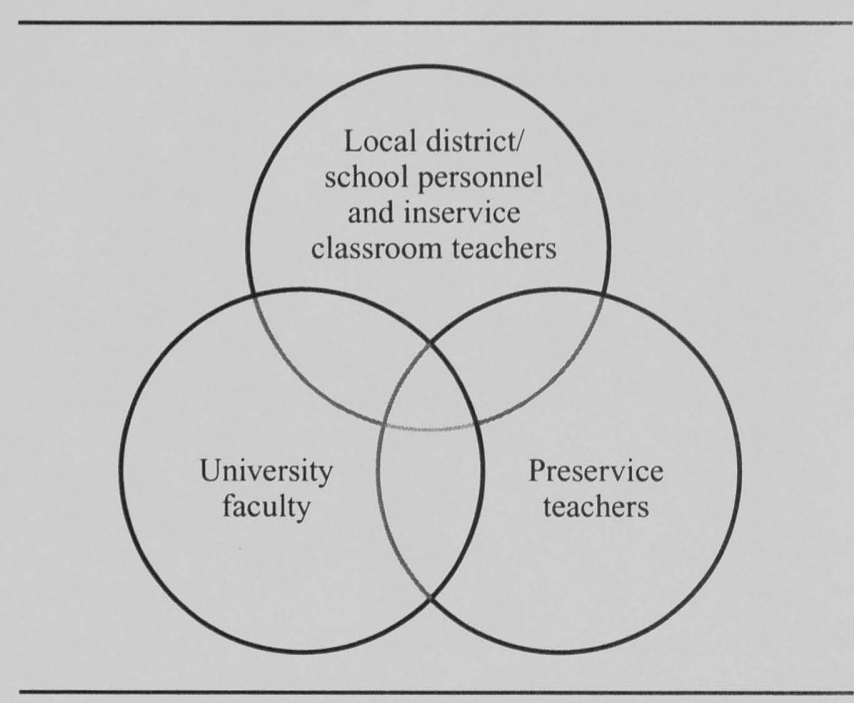

FIGURE 2:

Mutually Beneficial Relationships

teacher quality and collecting data on the effect of teacher training programs on $\mathrm{P}-12$ students. This phase of the 10year plan will require the development of sound measurement tools including observation, value-added statistical modeling, and student feedback. The Gates Foundation has begun work in this area by beginning to identify models of measurement for effective teaching (Bill and Melinda Gates Foundation, 2012). Further, Crowe (2010) lists recommendations for strengthening the evaluation of teacher education programs in higher education:

1. Tie $\mathrm{K}-12$ pupil learning outcomes to preparation program graduates and hold the programs accountable for teacher effectiveness.

2. Begin to implement high-quality observational assessments of classroom teaching by supporting efforts to link these assessments to student achievement and by developing rigorous training for classroom observers to ensure reliable assessment findings.

3. Employ current state data systems to track the teaching retention rates for graduates of every program and use the findings as a public disclosure measure.

4. Implement feedback surveys of preparation program graduates and their employers using state education, labor department (or state insurance department), university, and school district data systems.

Further work is needed to operationalize these recommendations; for example, when implementing recommendation 1 , how should a teacher preparation program be held accountable if its prior graduates are not maintaining high outcomes among their students? 


\section{Influence Policy and Future Reauthorizations}

The empirical evidence resulting from the previous phases of the plan has potential to impact policy development during future reauthorizations of federal education law. During future reauthorizations of ESEA, the field would provide evidence-based policy recommendations regarding highly qualified educators and accountability of career teachers as well as outcomes for student learners. Further, during reauthorization of the Higher Education Act, the field would provide evidence-based policy recommendations on the preparation and licensure of novice teachers and tie access to federal funds directly to improvements in their programs. In reauthorization of IDEA, the field would provide evidencebased recommendations on the benefits of including students with disabilities in the general curriculum and make clear guidelines for the instructional settings and arrangements promoting this. Finally, venturing into other reauthorizations, including the Education Sciences Reform and the Child Care and Development Block Grants Acts, the field would provide evidence-based recommendations for future research and improvements to early childhood care for greater school readiness, respectively. Developing an evidence base for the school-university partnership model of clinical preparation of teachers has wide-reaching implications for future policy development.

\section{For Teacher Educators}

Providing coursework in schools while maintaining a focus on literacy instruction and interventions within disciplines is a critical component of teacher preparation (Brownell et al., 2010). School-university partnerships enable candidates to practice data-based decision making through assessment, progress monitoring, and subsequent instructional planning. Engaging in partnerships provides context to teacher preparation coursework and facilitates higher order thinking about real-world problems the teacher candidates will face in the classroom. However, we would be remiss to overlook the challenges to such partnerships for university-based teacher education faculty. Teacher preparation curriculum would require revision, accreditation standards may be compromised, and tenure measures of productivity may not align with a partnership model. That said, traversing these barriers and the lessons learned by faculty will influence the direction of scaling up the school-university partnership model.

\section{For School and District Stakeholders}

Well-supported and well-funded preservice teachers have the potential to be invaluable to district and school personnel. Preservice teachers can be used for a variety of purposes while in their field-based learning. For example, schools can utilize more advanced teacher candidates to support differentiated learning groups, thereby increasing the amount of small-group instruction each student receives, whereas less experienced preservice teacher candidates may simply be an extra pair of ears and eyes as they learn the nuances of universal classroom management systems. The possibilities are endless for adding additional skilled and supported personnel in schools. Further, the opportunity to explore and understand school culture, to learn district policies, and to implement district curriculum gives teacher candidates, as well as school and district personnel, an advantage when hiring. That is, the candidate will be familiar with many of the nuances of partnering districts, while the school staff has firsthand experiences to judge how well the candidate will fit the position.

\section{CONCLUSION}

The NCATE report illustrates the ambitious agenda for substantial and sustainable change in teacher preparation. Policy makers emphasize the importance of outcomes for all students and provide financial incentives to states that adopt CCSS as a framework guiding instruction (USDOE, 2010). Teacher educators struggle with defining measures of effective teachers, let alone the skill set and experiences necessary to prepare teachers for complex and dynamic teaching environments (Tschannen-Moran \& Hoy, 2001). School leaders, as well as federal and state government officials, attempt to balance implementation with feasibility when adopting new educational models (Laczko-Kerr \& Berliner, 2002). There is no shortage of ideas about how to answer the question presented initially: How do we recruit, prepare, and retain effective teachers who will produce desired student outcomes in every classroom? However, resources for implementation of comprehensive reform are valuable and scarce. Research is clear: Effective teachers are the most critical resource provided to students in the classroom (Harris \& Sass, 2009); therefore, it is essential for teacher preparation to be in the forefront among concerns of school districts and the agenda for policy makers.

Although the NCATE report provides solid recommendations for a needed "overhaul" (NCATE, 2010, p. 2) of teacher preparation, it will have minimal influence on the process without the full support of other key stakeholders. Federal funding priorities, the CCSS movement (NGA, 2010), and reauthorization of ESEA, among others, must all contribute to mapping the trajectory for effective teacher preparation. As key stakeholders in this process, university teacher preparation faculty must strengthen their working relationships with state and local education agencies to form collaborative, innovative, research-based, and sustained partnerships 
driven by solving the problems teachers face in the classroom. To affect policy decisions, university teacher preparation faculty must foster relations with elected and unelected policy makers in the state and U.S. Capitol. Change is coming and teacher educators must be part of the equation.

\section{REFERENCES}

Albers, P., \& Goodman, J. (1999). Promoting meaningful discourse through early field experiences. Teaching Education, 10(2), $103-118$.

Andrew, M., \& Schwab, R. L. (1995). Has reform in teacher education influenced teacher performance? An outcome assessment of graduates of eleven teacher education programs, Action in Teacher Education, 17, 43-53.

Bill and Melinda Gates Foundation. (2012). Gathering feedback for teaching: Combining high-quality observations with student surveys and achievement gains. Seattle, WA: Author.

Billingsley, B. S. (2004). Special education teacher retention and attrition: A critical analysis of the literature. Journal of Special Education, 38(1), 39-55.

Billingsley, B. S. (2010). Work contexts matter: Practical considerations for improving new special educators' experiences in schools. Journal of Special Education Leadership, 23(1), 41-49.

Boyd, D. J., Grossman, P. L., Lankford, H., Loeb, S., \& Wykoff, J. (2009). Teacher preparation and student achievement. Educational Evaluation and Policy Analysis, 31(4), 416440.

Brownell, M. T., Griffin, C., Leko, M. M., \& Stephens, J. (2011). Improving collaborative teacher education research: Creating tighter linkages. Teacher Education and Special Education, 34(3), 235-249.

Brownell, M. T., Ross, D. D., Colón, E. P., \& McCallum, C. L. (2005). Critical features of special education teacher preparation: A comparison with general teacher education. Journal of Special Education, 38(4), 242-252.

Brownell, M. T., Sindelar, P. T., Kiely, M. T., \& Danielson, L. C. (2010). Special education teacher quality and preparation: Exposing foundations, constructing a new model. Exceptional Children, 76(3), 357-377.

Brownell, M. T., \& Smith, S. W. (1992). Attrition/retention of special education teachers: Critique of current research and recommendations for retention efforts. Teacher Education and Special Education, 15(4), 229-248.

Byrk, A. S., \& Gomez L. M. (2008). Ruminations on reinventing an R\&D capacity for educational improvement. In Hess, F. M. (Ed), The future of educational entrepreneurship: Possibilities for school reform. Cambridge, MA: Harvard Education Press.

Capraro, M. M., Capraro, R. M., \& Helfeldt, J. (2010). Do differing types of field experiences make a difference in teacher candidates' perceived level of competence? Teacher Education Quarterly, $37(1), 131-149$.

Carlone, H. B., \& Webb, S. M. (2006). On (not) overcoming our history of hierarchy: Complexities of university/school collaboration. Science Education, 90(3), 544-568. doi: 10.1002/sce.20123

Carnegie Forum on Education. (1986). A nation prepared: Teachers for the 21 st century. New York.

Cochran-Smith, S. (2005). The new teacher education: For better or for worse? Educational Researcher, 34(7), 3-17.
Coulter, G. (2003). Primetime: A university and local school partnership for the recruitment and training of preservice teachers. Teacher Education and Special Education, 26(4), 356-359.

Cozza, B. (2010). Transforming teaching into a collaborative culture: An attempt to create a professional development school-university partnership. Educational Forum, 74, 227-241.

Crowe, E. (2010, July). Measuring what matters: A stronger accountability model for teacher education. Center for American Progress, http://americanprogress.org

Cuban, L. (2008). Hugging the middle: How teachers teach in an era of testing and accountability. New York: Teachers College Press.

Darling-Hammond, L. (2007). A good teacher in every classroom: Preparing the highly qualified teachers our children deserve. Educational Horizons, 85(2), 111-132.

Darling-Hammond, L. (2010). Teacher education and the American future. Journal of Teacher Education, 61(1-2), 35-47.

Darling-Hammond, L., \& Bransford, J. (2005). Preparing teachers for a changing world: What teachers should learn and be able to do. Jossey-Bass.

Darling-Hammond, L., \& McLaughlin, M. W. (1995). Policies that support professional development in an era of reform. Phi Delta Kappan, 76, 597-604.

Deshler, D. D., \& Schumaker, J. B. (2006). High school students with disabilities: Strategies for accessing the curriculum. New York: Corwin Press.

Donovan, S. (2009). Building "institutional infrastructure": And bringing research into the classroom. Education Week, 28(21), 24-25.

Duncan, A. (2010, November). On supporting teachers. Remarks of Secretary of Education, New York, NY.

Ebbers, S. M., \& Denton, C. A. (2008). A root awakening: Vocabulary instruction for older students with reading difficulties. Learning Disabilities Research \& Practice, 23(2), 90-102.

Edmonds, M. S., Vaughn, S., Wexler, J., Reutebuch, C., Cable, A., Tackett, K. K., \& Schnakenberg, J. W. (2009). A synthesis of reading interventions and effects on reading comprehension outcomes for older struggling readers. Review of Educational Research, $79(1), 262-300$.

Faggella-Luby, M. N., \& Deshler, D. D. (2008). Reading comprehension in adolescents with LD: What we know; what we need to learn. Learning Disabilities Research \& Practice, 23(2), 70-78.

Feiman-Nemser, S., \& Buchmann, M. (1985). Pitfalls of experience in teacher preparation. Teachers College Record, 87(1), 53-65.

Fullen, M. (2007). The new meaning of educational change (4th ed.). New York: Teachers College Press.

Greer, D. L., \& Meyen, E. L. (2009). Special education teacher education: A perspective on content knowledge. Learning Disabilities Research \& Practice, 24(4), 196-203.

Harris, D. N., \& Sass, T. R. (2009). What makes for a good teacher and who can tell? CALDER Working Paper No. 30. Retrieved from http://www.urban.org/url.cfm?ID=1001431

Hess, F. (2010, November 16). NCATE's "transformative" vision ... not so much. [Web log post]. Retrieved from http://blogs.edweek.org/ edweek/rick_hess_straight_up/2010/11/ncates_transformative_vis ionnot_so_much.html

Hill, H. C., Ball. D. L., \& Schilling, S. G. (2008). Unpacking pedagogical content knowledge: Conceptualizing ad measuring teachers' topic-specific knowledge of students. Journal for Research in Mathematics Education, 39(4), 372-400.

Hollins, E. R. (2011). Teacher preparation for quality teaching. Journal of Teacher Education, 62(4), 395-407. 
Imig, D., Wiseman, D., \& Imig, S. (2011). Teacher education in the United States of America, 2011. Journal of Education for Teaching, 37(4), 399-408.

Kennedy, M. (2005). Inside teaching-How classroom life undermines reform. Cambridge, MA: Harvard University Press.

Kennedy, M. J., \& Deshler, D. D. (2010). Literacy instruction, technology, and students with learning disabilities: Research we have, research we need. Learning Disability Quarterly, 33, 289-298.

Kennedy, M. J., \& Ihle, F. M. (2012). The old man and the sea: Navigating the gulf between special educators and the content area classroom. Learning Disabilities Research \& Practice, 27(1), 44-54.

King-Sears, M. E., \& Bowman-Kruhm, M. (2011). Specialized reading instruction for adolescents with learning disabilities: What special education co-teachers say. Learning Disabilities Research \& Practice, 26(3), 127-184.

Laczko-Kerr, I., \& Berliner, D. C. (2002). The effectiveness of "Teach for America" and other under-certified teachers on student academic achievement: A case of harmful public policy. Education Policy Analysis Archives, 10(37). Retrieved from http://epaa.asu.edu/ ojs/article/view/316

Lefever-Davis, S., Johnson, S., \& Pearman, C. (2007). Two sides of partnership: Egalitarianism and empowerment in school-university partnerships. Journal of Educational Research, 100(4), 204-210.

Mastropieri, M. A., Scruggs, T. E., Graetz, J., Norland, J., Gardizi, W., \& McDuffie, K. (2005). Case studies in co-teaching in the content areas: Successes, failures, and challenges. Intervention in School and Clinic, 40(5), 260-270.

McKenzie, R. G. (2009). Elevating instruction for secondary-school students with learning disabilities by demystifying the highly qualified subject matter requirement. Learning Disabilities Research and Practice, 24, 143-150.

Mellard, D. F., Stern, A., \& Woods, K. (2011). RTI school-based practices and evidence-based models. Focus on Exceptional Children, 43(6), $1-16$.

National Center for Educational Statistics. (NCES). (2009, June). 2004/09 beginning postsecondary students longitudinal study (BPS:04/09) field test. Washington, DC: U.S. Department of Education.

National Council for Accreditation of Teacher Education. (NCATE). (2010). Transforming teacher education through clinical practice: A national strategy to prepare effective teachers. Report of the blue ribbon panel on clinical preparation and partnerships for improved student learning. Retrieved from http://www.ncate.org

National Governor's Association. (NGA). (2010). Common core state standards initiative: Preparing America's students for college and career. Retrieved from: http://www.corestandards.org

National Research Council. (NRC). (2011) Incentives and test-based accountability in education. Washington, DC: The National Academies Press.

Oyler, C. (2011). Teacher preparation for inclusive and critical (special) education. Teacher Education and Special Education, 34(3), 201-218.

Peel, H. A., Peel, B. B., \& Baker, M. E. (2002). School/university partnerships: A viable model. International Journal of Educational Management, 16(7), 319-325.

Piper, A. (2007). What we know about integrating early childhood education and early childhood special education teacher preparation programs: A review, a reminder, and a request. Journal of Early Childhood Teacher, 28, 163-180.

Prater, M. A., \& Sileo, T. W. (2004). Fieldwork requirements in special education preparation: A national study. Teacher Education and Special Education, 27(3), 251-263.

Pugach, M. C., \& Blanton, L. P. (2011). Preservice teacher preparation across general and special education: Interrogating the meaning of collaboration and its role in teacher education reform. Teacher Education and Special Education, 34(3), 181-182.

Pugach, M. C., Blanton, L. P., \& Correa, V. I. (2011). A historical perspective on the role of collaboration in teacher education reform: Making good on the promise of teaching all students. Teacher Education and Special Education, 34(3), 183-200.

Scammacca, N., Roberts, G., Vaughn. S., Edmonds, M., Wexler, J., Reutebuch, C. K., \& Torgesen, J. K. (2008), Interventions for adolescent struggling readers: A meta-analysis with implications for practice. Portsmouth, NH: RMC Research Corporation, Center on Instruction.

Scruggs, T. E., Mastropieri, M. A., Berkeley, S., \& Graetz, J. E. (2010). Do special education interventions improve learning of secondary content? A meta-analysis. Remedial and Special Education, 31(6), 437-449.

Scruggs, T. E., Mastropieri, M. A., \& McDuffie, K. A. (2007). Coteaching in inclusive classrooms: A meta-synthesis of qualitative research. Exceptional Children, 73, 392-416.

Shanahan, T., \& Shanahan, C. (2008). Teaching disciplinary literacy to adolescents: Rethinking content-area literacy. Harvard Educational Review, 78(1), 40-59.

Shulman, L. (1986). Those who understand: Knowledge growth in teaching. Educational Researcher, 15(2), 4-14.

Simonsen, B., Shaw, S. F., Faggella-Luby, M., Sugai, G., Coyne, M. D., Rhein, B., Madaus, J. W., \& Alfano, M. (2010). A schoolwide model for service delivery: Redefining special educators as interventionists. Remedial and Special Education, 31(1), 17-23.

Sindelar, P. T., Brownell, M. T., \& Billingsley, B. (2010). Special education teacher education research: Current status and future directions. Teacher Education and Special Education, 33(1), 8-24.

Skiba, R. J., Poloni-Staudinger, L., Simmons, A. B., Feggins-Azziz, R., \& Chung, C. G. (2005). Unproven links: Can poverty explain ethnic disproportionality in special education? The Journal of Special Education, 39, 130-144.

Stephens, D., \& Boldt, G. (2004). School/university partnerships: Rhetoric, reality, and intimacy. Phi Delta Kappan, 703-707.

Stronge, J. H., Ward, T. J., \& Grant, L. W. (2011). What makes good teachers good? A cross-case analysis of the connection between teacher effectiveness and student achievement. Journal of Teacher Education, 62(4), 339-355.

Sykes, G., Bird, T., \& Kennedy, M. (2010). Teacher education: Its problems and some prospects. Journal of Teacher Education, 61(5) 464476

Tschannen-Moran, M., \& Hoy, A. W. (2001). Teacher efficacy: Capturing an elusive construct. Teaching and Teacher Education, 17, 783-805

U.S. Department of Education. (USDOE). (2010). ESEA reauthorization: A blueprint for reform. Retrieved from http://www2.ed.gov/ policy/elsec/leg/blueprint/index.html

Vaughn, S., \& Fuchs, L. S. (2003). Redefining LD as inadequate response to instruction: The promise and potential problems. Learning Disabilities Research and Practice, 18, 137-146.

Wagner, M., Newman, L., Cameto, R., Levine, P., \& Garza, N. (2006). An overview of findings from Wave 2 of the National Longitudinal Transition Study-2 (NLTS2). (NCSER 2006-3004). Menlo Park, CA: SRI International. 
Wang, J., Odell, S. J., Klecka, C. L., Spalding, E., \& Lin, E. (2010). Understanding teacher education reform. Journal of Teacher Education, 61(5), 395-402.

Zeichner, K. (1980). Myths and realities: Field-based experiences in preservice teacher education. Journal of Teacher Education, 31(6), 45- $49,51-55$.

Zeichner, K. (2010). Rethinking the connections between campus courses and field experiences in college- and university-based teacher education. Journal of Teacher Education, 61(1-2), 89-99.

\section{STATEMENT OF OWNERSHIP, MANAGEMENT AND CIRCULATION}

Date of Filing: October 31, 2012

Title of Publication: Focus on Exceptional Children

Frequency of Issue: Monthly (except June, July \& August)

Location of Known Office of Publication: 9101 E. Kenyon Ave., Suite 2200, Denver, CO 80237

Location of Headquarters of Publisher: 9101 E. Kenyon Ave., Suite 2200, Denver, CO 80237

Name and Address of Publisher, Editor, and Managing Editor: Stanley F. Love, 9101 E. Kenyon Ave., Suite 2200, Denver, CO 80237

Owner: Love Publishing Company

Extent and Nature of Circulation: World Wide Academic

$\begin{array}{cc}\begin{array}{c}\text { Average No. Copies } \\ \text { Each Issue During }\end{array} & \begin{array}{c}\text { Single Issue } \\ \text { Nearest } \\ \text { Frling Date } \\ \text { Preceding 12 Months } \\ 1300\end{array} \\ 1300 \\ 32 & 32 \\ 997 & 997 \\ 61 & 58 \\ 1126 & 1100 \\ 30 & 20 \\ 56 & 32 \\ 1236 & 1174 \\ 64 & 126 \\ 1300 & 1300\end{array}$

Total No. Copies Printed

Paid Circulation

Sales through Dealers, etc.

Mail Subscriptions

Other Classes Mailed Through USPS

Total Paid Circulation

Free Distribution Outside the Mail

Total Free or Nominal Rate Distribution

Total Distribution

Office Use and Left Over

Total

1300

I certify that the statements made by me above are correct and complete.

(Signed) Stanley F. Love, Publisher

\section{PERMISSIONS AND COPYRIGHT}

All rights are reserved. No part of this publication may be reproduced, photocopied, faxed, stored in a retrieval system, or transmitted in any form or by any means, electronic, mechanical, recording or otherwise, without the prior written permission of the publisher.
Back issues are available for sale. Reproduction requires permission and payment of fees. It is illegal and a violation of federal copyright law to reproduce this publication without permission. Direct all inquiries to the permissions editor. 


\section{Collaborative Practitioners}

\section{Collaborative Schools}

\section{THIRD EDITION}

\section{Marleen C. Pugach • Lawrence J. Johnson Elizabeth R. Drame • Pamela Williamson}

Collaborative Practitioners, Collaborative Schools is an important resource for those who are building their capacity and skill for collaboration. This new edition continues to provide a vision of schools as learning communities, not just for students, but also for teachers, administrators, parents, and cross-institutional professionals.

Part One traces the development of collaborative partnerships in schools. Part Two breaks collaboration down into its component communication skills, illustrated by sample dialogues. Part Three explores the numerous contexts in which collaboration can help schools achieve educational goals and improve student learning. The third edition includes a new chapter on collaborating for curriculum decision making. It incorporates the latest in special education law, using technology to support collaboration, and educational research.

This revision continues its emphasis on diversity, home-school partnerships, and interagency teamwork. It outlines practical strategies for planning, implementing, and evaluating creative solutions to the challenges today's educators face.

978-0-89108-352-8 / paperback / 320 pages / C 2012

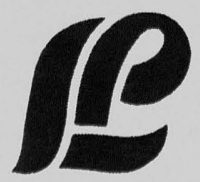

Love Publishing Company / Denver, Colorado 80222 www.lovepublishing.com / lpc@lovepublishing.com 


\section{Professional update}

\section{TASH 37th Annual Conference}

November 28-December 1, 2012

Long Beach, California

Contact: 202-540-9020

e-mail: conference@tash.org

www.tash.org

National Association of School Psychologists 45th Annual Conference

February 12-15, 2013

Seattle, Washington
Contact: $\quad 866-331-6277$
e-mail: convention@naspweb.org
www.nasponline.org

Council for Exceptional Children (CEC)

Annual Convention and Expo

April 3-6, 2013

San Antonio, Texas

Contact: $\quad 888-232-7733$

e-mail: service@cec.sped.org www.cec.sped.org

The American Counseling Association Conference and Exposition

March 20-24, 2013

Cincinnati, Ohio

Contact: $\quad 800-347-6647$

www.counseling.org 